\title{
Martin Wittek, Notes sur le monogramme de Philippe de Croy
}

\section{Giorgia Puttero}

\section{Q OpenEdition}

10 Journals

\section{Édition électronique}

URL : http://journals.openedition.org/studifrancesi/32846

DOI : $10.4000 /$ studifrancesi.32846

ISSN : 2421-5856

Éditeur

Rosenberg \& Sellier

\section{Édition imprimée}

Date de publication : 1 décembre 2005

Pagination : 617-618

ISSN : 0039-2944

\section{Référence électronique}

Giorgia Puttero, «Martin Wittek, Notes sur le monogramme de Philippe de Croy », Studi Francesi [En ligne], 147 (XLX | III) | 2005, mis en ligne le 30 novembre 2015, consulté le 18 avril 2021. URL : http:// journals.openedition.org/studifrancesi/32846 ; DOI : https://doi.org/10.4000/studifrancesi.32846

Ce document a été généré automatiquement le 18 avril 2021.

\section{(c) (i) (9)}

Studi Francesi è distribuita con Licenza Creative Commons Attribuzione - Non commerciale - Non opere derivate 4.0 Internazionale. 


\title{
Martin Wittek, Notes sur le monogramme de Philippe de Croy
}

\author{
Giorgia Puttero
}

\section{RÉFÉRENCE}

MARTIN WITTEK, Notes sur le monogramme de Philippe de Croy, «Scriptorium», 57, n. 2, 2003, pp. 272-276.

Comme le titre le suggère, cet article présente une étude sur les monogrammes de Philippe de croy tels qu'ils apparaissent sur quelques-uns des manuscrits qui ont appartenu à ce seigneur, issu d'une famille de bibliophiles liés aux ducs de Bourgogne. 